\title{
뇌졸중환자의 발병기간에 따른 과제지향훈련의 효과
}

\author{
성용수, $\mathrm{OT}^{1}$, 정상미, OT, $\mathrm{PhD}^{* 2}$ \\ ${ }^{1}$ 가천대학교 보건대학원 작업치료과, ${ }^{*}{ }^{2}$ 상지영서대학교 작업치료학과
}

The Effect of Task-oriented Movement Therapy Program Due to Duration of Onset of Stroke Patients

Yong-Soo Sung, OT $^{1}$, Sang-Mi Jung, OT, $\mathrm{PhD}^{* 2}$

${ }^{1}$ Dept. of Occupational Therapy, Graduate School of Public Health, Gachon University, Republic of Korea

${ }^{* 2}$ Dept. of Occupational Therapy, Sangji University, Republic of Korea

Purpose The purpose of this study was to find out an effective treatment method to improve affected side function and activity of daily living through task-oriented movement therapy that can be performed in daily life for stroke patients. Methods Task-oriented movement therapy was applied to six post-stroke patients twice a week, 30 minutes a day, for a total of four weeks. As a tool for evaluating the function of stroke patients, post-evaluation was performed 4 weeks after the pre-evaluation using the Korean Modified Barthel Index (K-MBI), Manual Functional Test (MFT), and Fugl-Meyer Assessment Scale (FMA). Results Through post-evaluation the following results were obtained significant improvements were made in both acute and chronic stroke patients and more significant improvements in acute patients with shorter incidence periods in K-MBI and MFT. FMA showed more significant improvements in chronic patients with longer periods of development, but significant improvements were observed in one chronic subject, comparing to acute patients. Conclusion Task oriented movement therapy was found to be effective for the functional recovery of affected side function and improvement of performance activity of daily living in acute and chronic stroke patients.

Key words Storke, task-oriented movement therapy, Activities of Daily Living, Upper extremity function, Duration of onset

Corresponding author Sang-Mi Jung (otjsm@hanmail.net)

Received date 04 October 2020

Revised date 08 October 2020

Accept date 13 October 2020

\section{I. 서 론}

뇌졸중은 뇌의 일부에 혈액을 제공하는 혈관이 터지거나 막힘 으로써 뇌혈관의 급성 신경학적 기능에 문제가 나타나 뇌의 혈류 공급의 문제로 인해 국소 기능 이상과 징후가 24 시간 이 상 관찰되는 것이다. ${ }^{1)}$ 또한 우리나라 사망 원인의 중요 질병 중 하나이며 현대의학의 발달로 인해 뇌졸중 사망률은 감소하 였고 생존하는 환자는 크게 증가하였다. 높은 생존율로 인해 뇌졸중 환자들의 신체적 기능 장애에 대한 재활의 중요성이 대두되고 있다. 생존한 뇌졸중 환자들의 허혈 및 출혈은 뇌 조직에 이상을 초래하고 궁극적으로 신체에 운동 및 감각의 손상과 더불어 인지 및 언어 등과 같이 전반적으로 뇌의 기능 과 관련된 신경학적 증상이 나타난다. ${ }^{2)}$

뇌졸중 발병 이후 가장 보편적인 후유증은 상지의 기능장

http:dx.doi.org/10.17817/2020.10.13.111573
애로 근육의 약화 및 마비, 비정상적인 근긴장도, 감각장애, 협응장애 등으로 인하여 손상 측 상지의 운동 능력이 뚜렷하 게 감소되면서 기능적 움직임에 어려움이 있다. ${ }^{3)}$ 특히 뇌졸중 발병 초기에는 환 측의 심한 운동장애를 가지는 환자 중 $20 \%$ 정도에서 상지기능이 일부분 회복되었고 $5 \%$ 미만에서 상지기 능이 완전하게 회복되었으므로 상지 기능 회복에 있어 부정적 이다. ${ }^{4)}$

뇌졸중 환자의 상지 운동 기능 장애에 따른 치료적 중재는 직접적으로 환 측 상지 회복을 위해 치료를 하거나 환 측 상 지의 완전한 기능적 회복보다는 다양하게 보상적 전략을 가르 치는 것과 같이 적용될 수 있다. ${ }^{5)}$ 또한 상지 기능과 운동 조 절을 향상시키기 위해 로봇재활, 양측성상지훈련활동, 강제유 도운동치료(Constraint Induced Movement Therapy, CIMT), 거울치료(mirror therapy) 등과 같은 새로운 접근 방법들을 시행하고 있다. ${ }^{\circ}$ 과제 지향 접근은 신경근계 및 근 골격계 등을 연결시키는 특수한 기능적 과제들에 중점을 둔 
훈련 프로그램으로 ${ }^{7)}$, 정상적 패턴들을 반복적으로 연습하기보 다는 기능적 과제에 중점을 두고 부여된 문제 해결을 위해 활 동적 움직임을 통해 배우는 것을 말한다. ${ }^{8)}$

과제 지향 훈련은 과제의 목적 달성에 필요한 능력을 훈련 시키고, 여러 환경에서의 적응을 향상시켜 실용적인 보상전략 과 문제해결력의 개발에 도움을 준다. ${ }^{9}$ 따라서 과제 지향 상 지 운동은 비 마비 측 상지보다 마비 측 상지의 능동적인 사 용을 장려하며 운동 기능을 최대한 이끌어 내고 회복하는데 치료의 목표를 둔다. ${ }^{10)}$

뇌졸중 환자의 과제 지향 훈련의 효과에 대한 선행 연구들 은 많았지만 뇌졸중 환자가 실제 일상생활에서 수행할 수 있 는 활동보다는 치료실 환경 안에서 과제를 수행하는 기능 중 심의 과제 지향 훈련의 연구들이라 일반화시키는 것은 어렵기 때문에 본 연구는 뇌졸중 환자를 대상으로 실제 일상생활에서 접할 수 있는 형태의 과제 중심으로 구성된 과제 지향적 훈련 을 통해 환 측의 기능과 일상생활활동을 증진 시키는 효율적 인 치료 방법을 알아보고자 한다.

\section{II. 연구 방법}

\section{1. 연구대상 및 기간}

본 연구의 대상은 2019년 6월 3일부터 6월 28일까지 4주간 진행하였다. 서울시 소재의 $\mathrm{M}$ 병원에서 재활치료를 받은 입원 환자들과 외래 환자들 중 뇌졸중 진단을 받은 환자를 대상으 로 연구에 대한 설명을 하였고 이에 동의하고 자발적으로 참 여한 6명(입원환자 5명, 외래환자 1명)을 대상으로 연구를 실 시하였다. 모든 연구 대상자들은 작업치료 및 물리치료 중재 를 병행 하였고 과제 지향 훈련의 중재는 주 2 회 1 일 30 분간 5 가지 과제 지향 훈련 프로그램을 적용 하였다.

연구 대상자의 선정 기준은 다음과 같다.

1) 뇌졸중으로 진단을 받은 자.
2) MMSE-K 20점 이상인 자로 검사자의 지시나 의사소통이 가능한 자.

3) modified Rankin Scale 3점 이하인 자.

4) 뇌졸중 이외의 정형외과적 질환이 없는 자.

본 연구에 참여한 대상자의 일반적 특성은 Tabel 1 과 같다.

\section{2. 대상자 선정 평가 도구}

(1) 한국형 간이 정신상태 판별검사(Mini-Mental State Examination- Korea, MMSE-K)

권용철과 박종한 ${ }^{11)}$ 이 MMSE(Mini Mental State Examination) 를 한글로 변역해서 표준화한 것으로 비교적 검사가 쉽고 검 사 시간은 5-10분 정도의 짧은 시간에 간편하게 검사할 수 있 다. 또한 연습에 의한 효과가 적어서 질병의 진행과정 동안에 반복 측정함으로써 경과에 따른 변화를 추적할 수 있는 장점 이 있다. ${ }^{11)}$ 또한 중등도와 중증치매환자의 구분에 타당도와 신뢰도가 입증되어 우리나라에서 가장 보편적으로 사용되는 검사법이다. ${ }^{12)}$ 이 도구는 검사자 간 신뢰도는 0.86 검사자 내 신뢰도는 0.96 으로 높은 내적 타당도와 신뢰도를 가지고 있 다. ${ }^{13)}$ 본 연구에서는 언어적 지시에 과제 수행이 가능한 20 점 이상 환자들을 대상으로 하였다.

(2) 수정랭킨척도(modified Rankin Scale, mRS)

$\mathrm{mRS}$ 는 뇌졸중 후에 기능장애의 정도를 평가할 수 있는 척도 로 일상생활에서의 동작을 평가하는 기능 평가 척도이대[14]. 아무런 증상이 없을 때를 0 점, 발병 전의 모든 업무와 일상에 서의 활동 시행이 가능한 경우를 1점, 발병 전의 모든 일상에 서의 활동을 수행할 수는 없지만 도움 없이 스스로 일상적 용 무는 처리할 수 있는 경도의 장애를 2점, 약간의 도움이 필요 하지만, 다른 사람들의 부축 없이 걸을 수 있는 중등도의 장 애를 3점, 보조나 다른 사람들의 도움이 없이 보행이 불가능 하고 대소변 처리와 위생 관리를 스스로 할 수 없는 중등도 고도의 장애를 4점, 침상 의존 상태이며 대소변 실금이 있고 지속적인 간호와 주의가 필요한 중증 고도의 장애를 5점, 사

Table 1. Characteristics of subjects in the study

\begin{tabular}{|c|c|c|c|c|c|c|}
\hline Characteristics & Subject 1 & Subject 2 & Subject 3 & Subject 4 & Subject 5 & Subject 6 \\
\hline Age (yr) / Gender & $77 / F$ & $47 / \mathrm{M}$ & $52 / \mathrm{F}$ & $72 / F$ & $67 / M$ & $66 / \mathrm{M}$ \\
\hline Onset period (mo) & 1 & 1 & 1 & 23 & 8 & 7 \\
\hline Type & $\begin{array}{c}\text { posterior cerebral } \\
\text { artery } \mathrm{ICH}\end{array}$ & $\begin{array}{l}\text { pontine } \\
\text { infarction }\end{array}$ & $\begin{array}{c}\text { basal ganglia } \\
\text { ICH }\end{array}$ & $\begin{array}{l}\text { cerebral } \\
\text { infarction }\end{array}$ & $\begin{array}{l}\text { pontine } \\
\text { infarction }\end{array}$ & thalamic ICH \\
\hline Affected side & right & left & left & right & right & right \\
\hline Separation & admission & admission & admission & admission & outpatient & admission \\
\hline MMSE-K & 20 & 29 & 27 & 27 & 27 & 23 \\
\hline mRS & 3 & 3 & 3 & 3 & 3 & 3 \\
\hline
\end{tabular}


망한 경우를 6점으로 하였다. 이 도구는 검사자 간 신뢰도는 0.62-0.91이대[15]. 본 연구에서는 3점 이하인 환자들을 대상 으로 하였다.

\section{3. 연구절차}

연구의 절차는 다음과 같다(Table 2).

\section{4. 연구도구}

(1) 한국형 수정 바델 지수(korean Modified Barthel Index, $\mathrm{K}-\mathrm{MBI})$

뇌졸중 환자들의 일상생활활동을 평가하기 위해 Shah, Vanclay과 Cooper ${ }^{16}$ 이 개발한 수정 바델 지수를 ${ }^{16)}$ 정한영 등 ${ }^{17)}$ 이 번역해서 보고한 K-MBI를 사용하였다. K-MBI는 식사 하기, 개인위생, 목욕하기, 용변처리, 옷 입기, 계단 오르기, 소 변 조절, 대변 조절, 보행, 의자 차, 의자/침대 이동의 11 개 문 항으로 구성되어 있고 의자 차 항목의 경우 보행이 가능하지 않은 경우에 보행 대신 측정하기 때문에 실제로 측정 문항은 총 10 개 문항이 된다. 각 항목은 5점 리커트 척도로써 수행 정 도에 따라 완전히 독립적인 경우에서부터 과제를 수행할 수 없 는 경우까지이다. 점수 체계는 5점에서 15점까지로 모든 항목 을 완전히 독립적으로 수행할 수 있는 경우는 100점이 된다. 정한영 등은 $\mathrm{K}-\mathrm{MBI}$ 의 구성 타당도를 보고하였으며, 검사자 간 신뢰도를 0.93-0.98, Cronbach $\alpha$ 를 0.84로 보고하였다.

(2) 상지기능검사 (Manual Functional Test, MFT)

뇌졸중 환자의 상지의 운동기능 변화를 측정하고 기록하기 위

Table 2. Research procedure

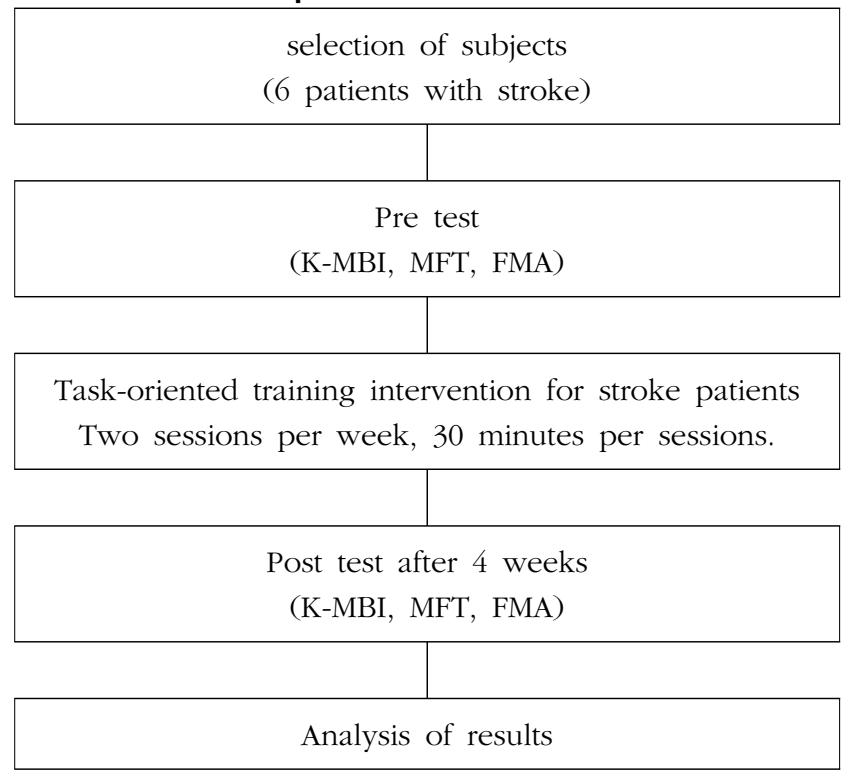

해 개발되었다. 신경학적 회복 시기에 있어 짧은 기간 동안의 변화를 측정할 수 있을 뿐만 아니라, 상지기능 및 동작 능력의 측정에 많이 쓰이는 도구이다. 뇌졸중 상지기능 검사는 상지운 동 4항목, 장악력 2항목, 손가락 조작 2항목으로 구성되어있고 양쪽 상지를 같이 평가하여 기능 회복 수준을 검사한다. 검사 자 내 신뢰도는 0.994 , 검사자 간 신뢰도는 0.993 이다. ${ }^{18)}$

(3) 감각운동기능평가(Fugl-Meyer Assessment Scale, FMA) Fugl-Meyer 평가 척도는 Fugl-Meyer, Jaasko, Leyman, Olsson과 Steglind ${ }^{19)}$ 에 의해 고안되었으며 뇌졸중 이후의 운 동 기능, 균형, 감각과 관절 기능의 일부를 측정하는 평가도구 이다[19]. 양측을 모두 평가하며 평가 항목의 수행 정도에 따 라 0 2점을 부여한다. 0점은 수행하지 못함, 1점은 부분적으 로 수행함, 2점은 완전 수행함이다. 전체 점수의 범위는 0 100점으로 상하지 모두를 포함하고 상지에 해당하는 검사 는 33항목으로 총점은 66점이고 하지 운동 기능 총점은 34 점 이다. 회복의 정도를 백분율로 나타낼 수 있으며 $\mathrm{FMA}$ 의 상지 검사 세부 항목은 어깨, 팔꿈치, 아래팔에 해당하는 18 항목, 손목 5항목, 손 7항목, 상지 협응 능력 3항목으로 검사자 간 및 검사자 내 신뢰도는 0.096 으로 높은 것으로 나타났다. ${ }^{20)}$

\section{5. 과제 지향 훈련 프로그램}

일상생활에서 수행되는 과제들로 환자의 기능적인 수행을 증 진시킬 목적으로 운동 처리 기술 평가(Assessment of Motor and Process Skills: AMPS)에서 제시하는 표준화된 과제 중 과제별 난이도 0.2-0.7 중 연구자 병원환경에 맞게 선정하여 적용하였다. 각 항목의 수행 시간은 5 분을 적용하였고 다음 항목을 시행하기 위한 이동 및 준비 시간을 1 분 적용하였다 (Table 3).

\section{6 분석방법}

본 연구는 개별 실험 연구방법으로 $\mathrm{A}, \mathrm{B}$ 설계를 사용하였으 며 기술 통계를 이용하여 평균과 표준편차로 능력의 변화를 분석하고 그래프화하여 제시하였다.

\section{III. 결 과}

\section{Korean Modified Barthel Index(K-MBI)}

$\mathrm{K}-\mathrm{MBI}$ 중재 전 점수는 평균 51.6점으로 중재 후 대상자1 38 점, 대상자2 18점, 대상자3 21점, 대상자4 5점, 대상자5 1점, 대상자6 13점으로 향상되어 변화량 평균 16점, 점수 평균 67.6점 향상되었고 발병 기간이 짧을수록 평균값의 향상을 보 였다(Table 4). 
Table 3. Task orientation program

\begin{tabular}{|c|c|}
\hline Task name & Task orientation program \\
\hline washing and wipe your 1 & $\begin{array}{l}\text { Wash your hands in the sink with liquid soap dry your hands completely using a paper } \\
\text { towel. }\end{array}$ \\
\hline $\begin{array}{l}\text { Retrieve a drink from the } \\
\text { refrigerator and pour it into a cup }\end{array}$ & $\begin{array}{l}\text { Open the refrigerator door and retrieve the drink. then, put the drink on the adjacent } \\
\text { sink, close the refrigerator and pour the drink into the cup. }\end{array}$ \\
\hline Wash the cup & Cleanse the cup using dish soap and a sponge. \\
\hline Clean the floor with a broom & sweep the floor with a broom. \\
\hline Fold and & $\begin{array}{l}\text { Take the towel from the desk, sit down in the chair, fold the towel, then place it on } \\
\text { top of desk. }\end{array}$ \\
\hline
\end{tabular}

Table 4. Comparison of $\mathrm{K}-\mathrm{MBI}$

\begin{tabular}{ccccc}
\hline Subject & mo & Pre test & Post test & Point \\
1 & 1 & 43 & 81 & 38 \\
2 & 1 & 60 & 78 & 18 \\
3 & 1 & 63 & 84 & 21 \\
4 & 23 & 54 & 59 & 5 \\
5 & 8 & 51 & 52 & 1 \\
6 & 7 & 39 & 52 & 13 \\
\hline \hline & M SD & Min. & Max. \\
Pre test & $51.6 \pm 9.3$ & 39 & 63 \\
Post test & $67.6 \pm 14.9$ & 52 & 84 \\
Point & $16 \pm 13.1$ & 1 & 38 \\
\hline
\end{tabular}

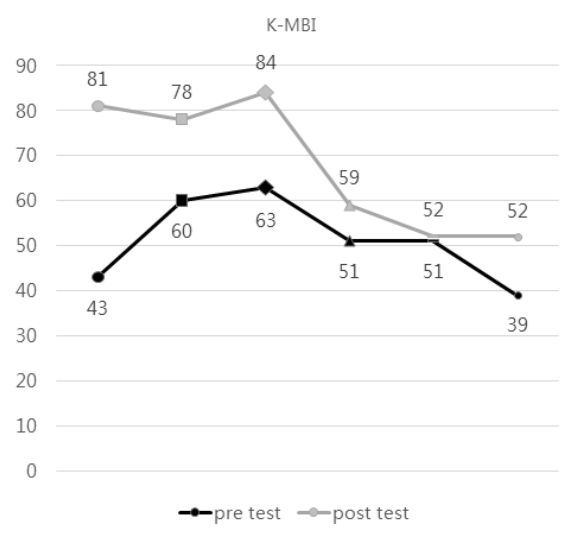

Table 5. Comparison of MFT

\begin{tabular}{ccccc}
\hline Subject & mo & Pre test & Post test & Point \\
1 & 1 & 24 & 27 & 3 \\
2 & 1 & 20 & 24 & 4 \\
3 & 1 & 16 & 24 & 8 \\
4 & 23 & 11 & 12 & 1 \\
5 & 8 & 14 & 15 & 1 \\
6 & 7 & 17 & 26 & 9 \\
\hline \hline & $M \pm$ SD & Min. & Max. \\
Pre test & $17 \pm 4.5$ & 11 & 24 \\
Pre test & $21.3 \pm 6.2$ & 12 & 27 \\
Point & $4.3 \pm 3.4$ & 1 & 9 \\
\hline
\end{tabular}

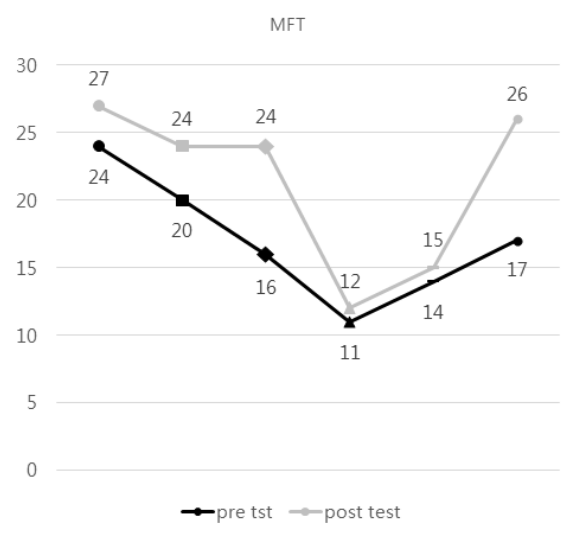

\section{Manual Functional Test (MFT)}

MFT 중재 전 점수는 평균 17점으로 중재 후 대상자1 3점, 대상자2 4점, 대상자3 8점, 대상자4 1점, 대상자5 1점, 대상
자6 9점 향상되어 변화량 평균 4.3점, 점수 평균 21.3점 향상 되었고 발병 기간이 짧을수록 평균값의 향상을 보였다(Table 5). 
Table 6. Comparison of FMA

\begin{tabular}{ccccc} 
Subject & mo & Pre test & Post test & Point \\
1 & 1 & 92 & 97 & 5 \\
2 & 1 & 82 & 93 & 11 \\
3 & 1 & 84 & 87 & 3 \\
4 & 23 & 60 & 63 & 3 \\
5 & 8 & 64 & 67 & 3 \\
6 & 7 & 65 & 92 & 27 \\
\hline \hline & M SD & Min. & Max. \\
Pre test & $74.5 \pm 13.1$ & 60 & 92 \\
Post test & $83.1 \pm 14.4$ & 63 & 97 \\
Point & $8.6 \pm 9.5$ & 3 & 27 \\
\hline
\end{tabular}

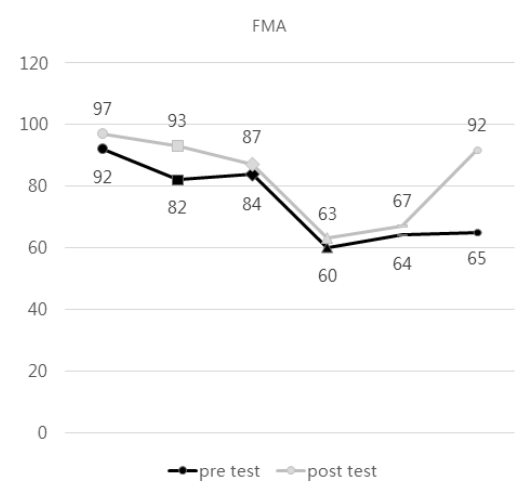

\section{Fugl-Meyer Assessment Scale (FMA)}

FMA 중재 전 점수는 평균 74.5점으로 중재 후 대상자1 5점, 대상자2 11점, 대상자3 3점, 대상자4 3점, 대상자5 3점, 대상 자6 27점으로 향상되어 변화량 평균 8.6점, 점수 평균 83.1점 향상이 되었고 발병 기간이 짧을수록 평균값의 향상을 보였지 만 발병 기간이 긴 대상자 6 의 두드러진 향상이 관찰되었다 (Table 6).

\section{IV. 고 찰}

Carr와 Shepherd ${ }^{21)}$ 에 의해 고안된 과제 지향 훈련은 운동학 습이론을 기반으로 뇌졸중 환자들을 위해 계발된 치료 방법 중의 한 형태로, 신경학적 결손을 가진 환자들의 치료를 위한 시스템 이론으로써 과제 특수화(task specific) 전략을 습득해 환자가 변화하는 환경에 적응할 수 있도록 도와주는 것이며 과제 지향 프로그램은 환자가 능동적으로 과제를 수행함으로 써 신경계에 있어 긍정적 변화를 유발할 수 있다." 뇌졸중 환 자에게 과제 지향 접근법을 사용한 치료 방법은 실제 일상생 활 동작 수행능력 증진에 효과를 볼 수 있는 과제들로 형성되 어 일상에서 다양한 활동을 기능적이고 효율적으로 훈련할 수 있는 치료방법이다. ${ }^{21)}$

본 연구는 뇌졸중 환자들을 대상으로 일상생활에서 수행할 수 있는 과제 지향적 훈련을 통해 마비 측의 기능과 일상생활 활동을 증진 시키는 효과에 대해 알아보았다. 초기의 정확한 인지 지각 기능의 평가는 환자의 기능을 증진시키기 위한 치 료 프로그램을 계획하는 데에 기초 선을 제공 할 수 있다. ${ }^{22)}$ 연구 대상자 선정 시 인지 기능 이상 유무를 확인하기 위하여 MMSE-K를 사용하여 언어적 지시에 과제 수행이 가능한 20 점 이상 환자들과 수정랭킨척도(mRS)를 사용하여 과제 수행 이 가능한 3점 이하의 환자들을 대상으로 선별 검사를 실시하
였고 연구 결과는 뇌졸중 환자들의 상지 기능의 향상과 일상 생활 활동 수행능력을 향상시키는 데 도움이 되는 것으로 나 타났고 발병 기간이 짧을수록 효과가 높게 나타났다.

일상생활활동을 평가하기 위한 K-MBI에서 6명 모두 점수 의 향상이 있었고 방요순 ${ }^{23)}$ 의 연구에서도 과제 지향적 훈련을 통해 일상생활 활동 수행능력이 향상됐음을 보고 하여 본 연 구 결과와 일치하였다. ${ }^{23)}$ 상지 기능을 평가하기 위한 MFT에 서 6명 모두 점수의 향상이 있었다. 운동 손상 정도를 양적으 로 평가하기 위한 FMA에서 6명 모두 점수의 향상이 있었고 정재훈 ${ }^{24)}$ 의 연구에서도 과제 지향적 상지 운동은 전통적 작업 치료 중재에 보다 뇌졸중 환자들의 환 측의 상지의 기능 향상 과 일상생활 수행능력을 향상시켰으며, 환측 상지의 기능 운 동과 연관된 일상생활활동 수행능력에 영향을 미친다고 보고 하였다. ${ }^{24)}$ 이것은 과제 지향 훈련이 뇌졸중 환자들에게 있어 신경학적이나 기능적 측면에서 도움이 되며 ${ }^{25)}$, 전반적으로 기 능을 증진시키는데 있어 효과적으로 사용될 수 있다는 선행 연구들의 결과를 지지하는 것이다. ${ }^{21,26,27,28)}$

일반적인 발병 기간은 뇌졸중 발병 직후 신경외과나 신경 과에 입원해서 침상 재활치료를 하는 곳이 많기 때문에 재활 의학과 전과 이전을 급성기 재활로 정의하고 발병 후 6 개월까 지 신경회복이 왕성하고 국내에서 환자들의 장애등급을 위한 진단서를 발부하게 되는 진단 후 6 개월이기 때문에 재활의학 과 전과 후 6 개월까지 아급성기로 장애등급을 재판정 하게 되 는 2 년까지를 만성기로 정의하였다. 그러나 김형섭 등 ${ }^{29)}$ 은 재 활의학과 전과 전후를 비교하기 어렵기 때문에 발병부터 6개 월까지를 아급성기로 정의하였고 발병 후 6 개월에서부터 2 년 까지를 만성기로 다시 정의하였다. ${ }^{29)}$

$\mathrm{K}-\mathrm{MBI}$ 는 중재 후 변화량 평균 16 점이 증가하였고 MFT 는 중재 후 변화량 평균 4.3점이 증가했으며 FMA는 중재 후 변화량 평균 8.6점이 증가하여 전반적으로 발병 기간이 짧은 환자에게서 더 많은 점수의 향상을 보였다. 뇌졸중 후에 기능 
회복이 주로 초창기에 이루어진다는 것을 고려해 보았을 때 ${ }^{30)}$ 본 연구 결과 과제 지향 훈련이 발병 기간이 짧은 급성기 환 자에게 더욱 효과적으로 적용될 것으로 여겨진다. FMA의 경 우 발병 기간이 오래된 만성기 환자 중 대상자 6에서 기능 향 상이 두드러지게 관찰되었다. 움직임은 개인, 과제, 환경이 상 호작용에서 나오고 움직임은 환경적 요구와 과제에 맞춰서 체 계화된다. 개인은 특정한 환경 안에서 수행되는 과제가 요구 하는 것을 충족시키기 위하여 움직임을 일으킨다. ${ }^{25)}$ 환경 요 소와 학습은 전에 있던 신경 통로의 효율성을 변화시킴으로써 특별한 능력을 갖게 만든다. ${ }^{31)}$ 이러한 환경적 요인에 의해 발 병 기간이 긴 만성기 환자의 기능 회복이 향상되었을 것이다. 따라서 과제 지향 훈련은 급성기 및 만성기 뇌졸중 환자의 마 비 측 기능 회복과 일상생활활동의 수행능력 향상에 효과가 있었음을 알 수 있었다.

본 연구의 제한점으로 표본의 수가 적었으며 연구자 병원 특성상 훈련 기간의 설정이 짧아 일반화하기엔 부족하지만, 기존의 연구들을 지지하는 결과를 보여주었다는 것에 의미가 있다. 따라서 향후 연구에서는 치료 효과를 검증하기 위한 충 분한 대상자와 프로그램의 장기적 효과를 확인할 수 있는 연 구가 이어져야 할 것이다.

\section{References}

1. Kim YS, The Effects of FES on Ankle Dosiflexors for the Stroke Patients, 2005.

2. Trombly CA, Radomski MV. Occupational therapy for physical dysfunction.7thed, 2013

3. Trombly CA, Radomski MV, Trexel C, et al. Occupational therapy and achievement of self-identified goals by adults with acquired brain injury: phase II. Am J Occupational Therapy. 2002;6(5):489-98.

4. Hayward K, Barker R, Brauer S. Interventions to promote upper limb recovery in stroke survivors with severe paresis: A systematic review. Disability and Rehabilitation. 2010;32(24):1973-86.

5. Zorowitz RD, Gross E, Polinski DM. The stroke survivor, Disability and Rehabilitation. 2002;24(13):666-79.

6. Amit K, Sunil P. Effect of occupational therapy task oriented approach on recovery of upper-extremity motor function and activities motor function and activities of daily living in stroke patients, The Indian Journal of Occupational Therapy. 2009;41(2): 31-36.

7. Yang YR, Wang RY, Lin KH, et al. Task-oriented progressive resistance strength training improves muscle strength and functional performance in individuals with stroke, Clinical Rehabilitation. 2006; 20(10):860-70.

8. Kim JW, Kim SM, Park RJ. The Effects of Task-Oriented Functional Training on Standing Balance in Stroke Patients. The Journal of Korean Society of Physical Therapy. 2003;15(4):923-36.

9. Carr JH, Shepherd RB. In movement science foundations for physical therapy in rehabilitation. Austin, Pro-Ed. 2000.

10. Dromerick AW, Edwards DF, Hahn M. Does the application of constraint-induced movement therapy during acute rehabilitation reduce arm impairment after ischemic stroke. Stroke. 2000;31(12):2984-8.

11. Kwon YC, Park JH. Standardization of Korean Version of the Mini-Mental State Examination (MMSE-K) for Use in the Elderly. Part II. Diagnostic Validity, J Korean Neuropsychiatr Assoc. 1989;28(3):508-13.

12. Shin JH. Diagnosis of Dementia: Neuropsychological Test, Korean Journal of Family Medicine. 2010;31(4): 253-66.

13. Kang YU. A Normative Study of the Korean-Mini Mental State Examination (K-MMSE) in the Elderly, The Korean journal of school psychology. 2006; 25(2):1-12.

14. Wilson JT, Hareendran A, Grant M, et al. Improving the assessment of outcomes in stroke: use of a structured interview to assign grades on the modified Rankin Scale. Stroke. 2002;33(22):2243-6.

15. van Sweiten JC, Koudstaal PJ, Visser MC, et al. Interobserver agreement for the assessment of handicap in stroke patients. Stroke. 1988;19:604-7.

16. Shah S, Vanclay F, Cooper B. Improving the sensitivity of the Barthel Index for stroke rehabilitation, Journal of Clinical Epidemiology. 1989;42(8):703-9.

17. Jung HY, Park BK, Shin HS, et al. Development of the Korean Version of Modified Barthel Index (K-MBI) Multi-center Study for Subjects with Stroke, Annals of Rehabilitation Medicine. 2007;31(3):283-97.

18. Kim MY. A Study of Manual Functional Test for C.V.A., The Journal of Korean Society of Occupational Therapy. 1994; 2(1):19-26.

19. Fugl-Meyer AR, Jaasko L, Leynman OS, et al. The post-stroke hemiplegic patient: A method for evaluation of physical performance, Scandinavian Journal of Rehabilitation Medicine. 1975;7(2):13-31. 
20. Duncan PW, Propst M, Nelson SG. Reliability of the Fugl Meyer Assessment of sensorimotor recovery following cerebrovascular accident, Physical Therapy. 1983;63(2): 1606-10.

21. Carr JH, Shepherd RB. Stroke Rehabilitation : Guidelines for exercise and training to optimize motor skill, Butterworth-Heinemann. 2003.

22. Cermark SA, Kate N, McGuire E, et al. Performance of Americans and Israelis with cerebrovascular accident on Loewenstein Occupational Therapy Cognitive Assessment(LOTCA), American Journal of Occupational Therapy. 1995;49(1):500-6.

23. Bang YS. The Effects of Task-Oriented Activities on the Cognitive Function and Performance of Activities of Daily Living in Stroke Patients, The Journal of Korean Society of Occupational Therapy. 2007;15(3):49-61.

24. Jung JH. The Effect of Task-Oriented Movement Therapy on Upper Extremity, Upper Extremity Function and Activities of Daily Living for Stroke Patients. 2009.

25. Shumway-Cook, Woollat C. Motor control Translating Research into Clinical Practice 3rd edition, Lippincott Williams \& Wikins. 2007.
26. KIM JH, Jung MG. Effect of Task-Oriented Training Including Aftereffect After Applying rTMS on Hand Spasticity in Stroke Patients, The Journal of Korean Society for Neurotherapy. 2017;21(2):21-9.

27. Song BK, Kim AR, Kim JS, et al. A Systematic Review on The Task-Oriented Training Effect Applied to Hemiplegic Patients after Stroke, The Journal of Korean Society for Neurotherapy. 2019;23(2):35-43.

28. Jeon JH, Chang WN, Hwang BW. Effects of Task-Oriented Training in Water on Balance and Gait in Patients with Hemiplegia, The Journal of Korean Society for Neurotherapy. 2019;23(1):15-23.

29. Kim HS, Kim JM, Lim HS, et al. A study on the creation of evidence for efficient rehabilitation through analysis of acute medical use of stroke patients, National Health Insurance Service Ilsan Hospital. 2015.

30. Teasell R, FoleyN, Bhogal S, et al. An evidence based review of stroke rehabilitation, Topics in Stroke Rehabilitation, 2003;10(1):29-58.

31. Kandel E. Cellular mechanisms of learning and the biological basis of individuality, Principles of neural science. 1991. 
